\title{
Komunikasi Interpersonal melalui Layanan Bimbingan Kelompok di STAI Maarif Jambi
}

\section{Yulianti ${ }^{1}$, Ria Hayati ${ }^{2}$}

${ }^{1}$ Bimbingan Konseling Pendidikan Islam (BKPI), Sekolah Tinggi Agama Islam (STAI) Ma'arif Jambi, Indonesia

${ }^{2}$ Program Studi Bimbingan Konseling Islam, Universitas Islam Negeri (UIN) Sumatera Utara, Indonesia yuli56667@gmail.com, riahayaticaem@gmail.com

$\begin{array}{ccc}\text { First received: } & \text { Revised: } & \text { Final Accepted: } \\ \text { 01 November } 2021 & 20 \text { November } 2021 & 04 \text { November } 2021\end{array}$

\begin{abstract}
This study aims to determine the application of group guidance services to develop colage student interpersonal communication in STAI MAARIF JAMBI study program BKPI. The research method used is descriptive qualitative. Data obtained from interviews, observations and documentation sourced from students of the BKPI Study Program STAI MAARIF JAMBI. The collected data is followed up with data reduction, data display and drawing conclusions. Group guidance service is one of the services that exist in counseling guidance services, where group guidance services aim to train students to dare to express their opinions, train to convey solutions, practice critical thinking. Group guidance services are expected to be able to improve students' skills in good communication.
\end{abstract}

Keywords: Interpersonal Communication, Group Guidance Service, Colage Student

\begin{abstract}
ABSTRAK
Penelitian ini bertujuan untuk mengetahui penerapan layanan bimbingan kelompok guna mengembangkan komunikasi interpersonal mahasiswa di prodi BKPI STAI MAARIF JAMBI. Metode penelitian yang digunakan adalah kualitatif deskriptif. Data yang diperoleh dari hasil wawancara, observasi dan dokumentasi yang bersumber dari mahasiswa Prodi BKPI STAI MAARIF JAMBI. Data yang terkumpul ditindaklanjuti dengan reduksi data, display data dan menarik kesimpulan. Layanan bimbingan kelompok adalah salah satu layanan yang ada dalam layanan bimbingan konseling, yang mana layanan bimbingan kelompok bertujuan untuk melatih mahasiswa untuk berani menyampaikan pendapatnya, melatih untuk menyampaikan solusi, berlatih untuk berfikir kritis. Layanan bimbingan kelompok diharapkan mampu untuk meningkatkan keterampilan mahasiswa dalam berkomunikasi yang baik.
\end{abstract}

Kata kunci : Komunikasi Interpersonal, Bimbingan Kelompok, Mahasiswa 


\section{PENDAHULUAN}

Pendidikan adalah proses belajar mengajar yang yang dapat menghasilkan perubahan tingkah laku. Segera setelah dilahirkan mulai terjadi proses belajar pada diri anak dan hasil yang diperoleh yaitu kemampuan menyesuaikan diri dengan lingkungan dan pemenuhan kebutuhan. Pendidikan diselenggarakan dalam bentuk kegiatan belajar mengajar yang dilaksanakan di sekolah maupun diluar sekolah. Melalui jalur pendidikan sekolah adalah pendidikan yang diselenggarakan di sekolah melalui kegiatan belajar mengajar secara berjenjang dan berkesinambungan, adapun jalur pendidikan itu terdiri atas : pendidikan dasar, pendidikan menengah dan pendidikan tinggi. Selain jenjang tersebut, dapat juga diselenggarakan pendidikan anak usia dini yang dicapai sebelum jenjang pendidikan dasar.

Berdasarkan Undang-undang no.20 tahun 2003 tentang Sistem Pendidikan Nasional, Pasal 3 berbunyi “Tujuan dari pendidikan Nasional mengembangkan potensi peserta didik agar menjadi manusia yang beriman dan bertaqwa kepada Tuhan Yang Maha Esa berkakhlak mulia, sehat, berilmu, cakap, kreatif, mandiri dan menjadi warga Negara yang demokratis serta bertanggung jawab.

Manusia dilahirkan sebagai
makhluk sosial, yang mana sangat
membutuhkan oranglain dan ingin
mengetahui apa yang terjadi dengan
dirinya. Rasa ingin tahu ini
berkomunikasi dengan orang banyak. Komunikasi merupakan aktivitas manusia sehari-hari, sesama jenis ataupun lawan jenis. Dengan demikian komunikasi adalah aktivitas yang dilakukan oleh semua manusia dan membutuhkansebuah keterampilan khusus agar dapat melahirkan kesuksesan. Mahasiswa sebagai bagian dari masyarakat dituntut dapat berkomunikasi dengan orang lain di lingkungan dimana mahasiswa berinteraksi. Lingkungan yang dimaksud adalah kampus, karena hampir sebagian waktu mahasiswa banyak digunakan untuk berinteraksi dengan orang lain.

Di lingkungan kampus mahasiswa akan senantiasa berkomunikasi dengan teman sebayanya, dengan dosendosennya, dan dengan tenaga kependidikan yang senantiasa mereka temui di lingkungan kampus. Tugas pokok mahasiswa di kampusadalah belajar, dengan belajar mahasiswa akan 
memperoleh perubahan yang positif dan dapat berkembang secara optimal serta siap melaksanakan peranannya di masa yang akan datang. Belajar bersosialisasi dan berkomunikasi dengan lingkungan sekitar merupakan proses perkembangan psikomotorik, afektif, dan kognitif dalam kehidupanindividu. Mahasiswa adalah anak yang menjalani proses pembelajaran.

Pihak prodi menyadari perlunya dilakukan upaya khusus untuk meningkatkan kemampuan berkomunikasi pada para siswanya. Upaya yang dilakukan untuk peningkatan keterampilan berkomunikasi dapat dilakukan dengan mengadakan kegi-atan layanan bimbingan kelompok, mengi-ngat bimbingan kelompok mempunyai berbagai macam kelebihan. Pertama dengan bimbingan kelompok, anggota kelompok dapat berinteraksi dan saling mengeluarkan pendapat, memberi-kan tanggapan, saran, dan sebagainya.

Kedua dengan bimbingan kelompok mahasiswa dapat saling memahami antar anggota kelompok sehingga timbul sikap percaya. Sikap percaya inilah yang membuat mahasiswa dapat terbuka untuk mengutarakan isi hatinya. Ketiga dalam bimbingan kelompok mahasiswa dilatih untuk mengkomunikasikan pikiran dan perasaan secara tepat dan jelas sehingga secara tidak langsung semua anggota kelompok dapat berlatih untuk berkomunikasi. Keempat dalam bimbingan kelompok, anggota kelompok dilatih untuk mampu memecahkan konflik dan bentuk-bentuk masalah antar pribadi lain yang mungkin muncul dalam komunikasi dengan orang lain melalui cara-cara yang konstruktif.

Selain itu kelima aspek keefektifan perilaku komunikasi antarpribadi menurut Kumar (Wiryanto, 2004:36) yang meliputi keterbukaan, rasa positif, empati, dukungan dan kesetaraan tertampung dalam kegiatan layanan bimbingan kelompok, bukan pada layanan bimbingan konseling lainnya. Dalam bimbingan kelompok terdapat dinamika kelompok yang dapat memunculkan interaksi positif sehingga diharapkan secara optimal siswa dapat mengalami perubahan dan mencapai peningkatan yang positif setelah mengikuti kegiatan bimbingankelompok.

Setiap melaksanakan layanan bimbingan kelompok terdapat beberapa faktor yang memengaruhi keefektifan layanan bimbingan kelompok. Faktorfaktor ini berupa faktor situasional dan faktor personal. Faktor situasional berarti 
bagaimana bimbingan kelompok tersebut dilakukan dan faktor personal menjelaskan sikap dan kemampuan anggota kelompok dapat memahami materi yang didiskusikan dalam layanan bimbingan kelompok. Hal ini yang menyebabkan setiap kegiatan layanan bimbingan kelompok memiliki tingkat keefektifan yang berbeda-beda. Depdikbud (1995: 1043) menyatakan bahwa keterampilan merupakan kecakapan, kepandaian, kemampuan untuk menyelesai-kantugas. Effendy (2009: 9) mengemukakan bahwa istilah komunikasi atau dalam Bahasa Inggris comunication berasal dari kata Latin communication, dan dari kata communis yang berarti sama makna. Jadi apabila dua orang terlibat dalam komunikasi misalnya dalam bentuk percakapan, maka komunikasi akan terjadi atau berlangsung selama ada kesamaan makna mengenai apa yang dipercakapkan.

Moor (Rohim, 2009: 8) menambahkan komunikasi adalah penyampaian pengertian antar individu. Ia menyatakan pula bahwa semua manusia dilandasi kapasitas untuk menyampaikan maksud, hasrat, perasaan, pengetahuan dan penga-laman dari orang yang satu kepada orang yang lain. Pada intinya komunikasi adalah pusat minat dan situasi perilaku di mana suatu sumber menyampaikan pesan kepada orang penerima dengan berupaya memengaruhi perilaku penerima tersebut.

Secara singkat, dapat disimpulkan bahwa keterampilan berkomunikasi adalah proses interaksi kegiatan manusia yang terdiri atas dua orang atau lebih yang saling memengaruhi dan bertukar informasi, pengetahuan, pikiran agar dapat menggu-gah partisipasi satu sama lain, sehingga informasi yang diberitahukan tersebut menjadi milik bersama.

\section{METODE}

Penelitian ini merupakan penelitian kualitatif yang bersifat deskriftif yang menggambarkan secara sistematis mengenai hal-hal yang ditemukan melalui wawancara, observasi dan dokumentasi. Penelitian ini dilaksanakan di STAI MAARIF JAMBI pada mahasiswa prodi BKPI semester 5, penelitian ini dilaksanakan pada bulan September sampai dengan November.

Subjek penelitian yang peneliti pilih adalah mahasiswa prodi BKPI semester 5 yang mengampu mata kuliah layanan bimbingan kelompok. Wawancara dan dokumentasi juga 
dilakukan dalam penelitian ini. Observasi langsung yaitu peneliti terlibat langsung dalam kegiatan layanan bimbingan kelompok. Wawancara dilakukan kontak mata,tatap muka dengan sumber data penelitian, yaitu dengan dosen BK, dan mahasiswa. Dokumentasi yaitu keseluruhan kegiatan yang berlangsung difoto beserta foto-foto kegiatan pendukung lainnya.

\section{HASIL DAN PEMBAHASAN}

Layanan bimbingan kelompok adalah layanan primadona di sekolah artinya layanan semestinya dijadikan sarana untuk meningkatkan keterampilan siswa karena pada layanan ini terdapat dinamika kelompok. Salah satu keterampilan yang penting adalah keterampilan berargumentasi, melalui bimbingan kelompok terjadi dinamika kelompok yang dapat menambah wawasaan anggota kelompok untuk menjadi lebih bijaksana dalam berkomunikasi. Keterampilan berkomunikasi penting karena pada zaman modern komunikasi adalah sarana untuk menjalin persahabatan bahkan persatuan dan kesatuan bangsa.

Peningkatan keterampilan berkomunikasi tersebut ditandai dengan siswa dapat saling memahami dan saling
Data yang telah terkumpul kemudian dianalisis menggunakan model Miles \& Huberman yang meliputi reduksi data, mendisplay data serta menarik kesimpulan. Setelah data di reduksi, data yang telah didapatkan didisplay sesuai dengan kejadian yang sebenar-benarnya, lalu barulah ditarik kesimpulan dari hasil data yang telah dianalisis sesuai dengan model Miles \& Huberman. mengerti, siswa dapat menghargai pendapat orang lain, siswa berbicara dengan sopan pada guru, tidak menyela pembicaraan, jika berbicara tidak menyinggung dan menyakiti hati orang lain baik disengaja maupun tidak disengaja, siswa aktif dalam kegiatan belajar mengajar, ketika berbicara di depan kelas siswa lebih percaya diri, dan tidak malu bertanya tentang materi yang disampaikan.

Dari hasil analisis yang berasal dari wawancara dan observasi data menunjukkan bahwa terjadi peningkatan keterampilan berkomunikasi antara sebelum dan sesudah dilakukan bimbingan kelompok yang terdiri dari tahap pembuka, peralihan, kegiatan, dan penutup. Hasil posttest menunjukkan adanya peningkatan skor rata-rata keteram-pilan berkomunikasi pada setiap 
kelompok. Berdasarkan hasil analisis data penelitian maka dikatakan bahwa perlakuan bim-bingan kelompok yang dilakukan merupakan jenis layanan yang efektif untuk mengembangkan keterampilan berkomuni-kasi siswa. Hal ini karena subjek penelitian setelah mendapat bimbingan kelompok, berdasarkan data yang diperoleh menunjuk-kan adanya peningkatan keterampilan berkomunikasi dengan ratarata peningkatan yang signifikan.

Setiap melaksanakan layanan bimbing-an kelompok terdapat beberapa faktor yang memengaruhi keefektifan layanan bimbingan kelompok. Ini sesuai dengan penelitian Syahrul (2015) yang menyatakan bahwa Layanan bimbingan kelompok adalah layanan primadona di sekolah artinya layanan semestinya dijadikan sarana untuk meningkatkan keterampilan siswa karena pada layanan ini terdapat dinamika kelompok.

Salah satu keterampilan yang penting adalah keterampilan berargumentasi, melalui bimbingan kelompok terjadi dinamika kelompok yang dapat menambah wawasaan anggota kelompok untuk menjadi lebih bijaksana dalam berkomunikasi. Keterampilan berkomunikasi penting karena pada zaman modern komunikasi adalah sarana untuk menjalin persahabatan bahkan persatuan dan kesatuan bangsa. Ini sesuai dengan penelitian Purwanti (2010).

Peningkatan keterampilan berkomunikasi tersebut ditandai dengan siswa dapat saling memahami dan saling mengerti, siswa dapat menghargai pendapat orang lain, siswa berbicara dengan sopan pada guru, tidak menyela pembicaraan, jika berbicara tidak menyinggung dan menyakiti hati orang lain baik disengaja maupun tidak disengaja, siswa aktif dalam kegiatan belajar mengajar, ketika berbicara di depan kelas siswa lebih percaya diri, dan tidak malu bertanya tentang materi yang disampaikan.

\section{KESIMPULAN DAN SARAN}

Berdasarkan hasil penelitian yang menunjukkan bahwa bimbingan kelompok efektif meningkatkan keterampilan berkomunikasi siswa, maka seyogyanya para dosen selalu menerapkan layanan bimbingan kelompok di sela-sela jam kosong agar mahasiswa semakin terlatih untuk berkomunikasi. Layanan bimbingan dan konselingmelakukan kegiatan bimbingan kelompok secara terjadwal bagi siswa 
sehingga diharapkan siswa mampu memiliki keterampilan berkomunikasi yang baik.

\section{DAFTAR PUSTAKA}

Arikunto, S. (2006). Prosedur Penelitian Suatu Pendekatan dan Praktik, Jakarta: Rineka Cipta.

Depdikbud. (1995). Kamus Besar Bahasa Indonesia, Jakarta: Balai Pustaka.

Effendi, O. U. (2009). Ilmu Komunikasi (Teori dan Praktek), Bandung: PT. Remaja Rosdakarya.

Lasswell, H. D. \& Kaplan, A. (1970). Power of Society, New Haven: Yale University Press.

Lunardi, A. G. (2001). Komunikasi Mangena, Yogyakarta: Kanisius.

Prayitno. (1995). Layanan dan Bimbingan Konseling Kelompok, Jakarta: Ghalia Indonesia.

Purwanti, I.Y. (2010). Layanan Bimbingan Kelompok untuk Mengurangi Kesulitan Belajar, UNY

Susanto, A. 2014. Perkembangan Anak Usia Dini Pengantar dalam Berbagai Aspeknya. Jakarta: Kencana Prenadamedia Group.

Gumittiri, A. M. 2018. Efektivitas Metode Pembelajaran Field Trip Terhadap Peningkatan Kecerdasan Naturalis Anak Di Taman Kanak-Kanak Pertiwi Dampang Kabupaten Bantaeng. Artikel. Makassar: Program pascasarjana Universitas negeri Makassar.
Seefeldt, C., \& Barbara A. W. 2008. Pendidikan Anak Usia Dini Menyiapkan Anak Usia Tiga, Empat dan Lima Tahun Masuk Sekolah. Jakarta: PT. Indeks.

Mubayidh, M. 2006. Kecerdasan dan Kesehatan Emosional Anak. Jakarta: Pustaka Al-Kautsar.

Santrock, J. W. 2011. Masa Perkembangan Anak-Children. Jakarta: PT. Salemba Humanika.

Marwiyati, S., \& Istianingsih. 2020. Pembelajaran Saintifik pada Anak Usia Dini dalam Pengembangan Kreativitas di Taman Kanak-Kanak. Jurnal. Published. Yogyakarta: Universitas Islam Negeri Sunan Kalijaga Yogyakarta.

Suyadi. 2009. Psikologi Belajar PAUD. Yogyakarta. Pedagogia.

Romlah, T. (2001). Teori dan Praktek Bimbingan Kelompok, Malang: UNM.

Syahrul, M. (2015). Layanan Bimbingan Kelompok terhadap Peningkatan Penyesuaian Siswa, 1(1), 46-60.

Supratiknya. (1995). Komunikasi Antarpribadi Tinjauan Psikologis, Yogyakarta: Kanisius.

Widjaja. (2000). Ilmu Komunikasi (Pengantar Studi), Jakarta: Rineka Cipta.

Wiryanto. (2004). Pengantar Ilmu Komunikasi, Jakarta: Grasindo. 